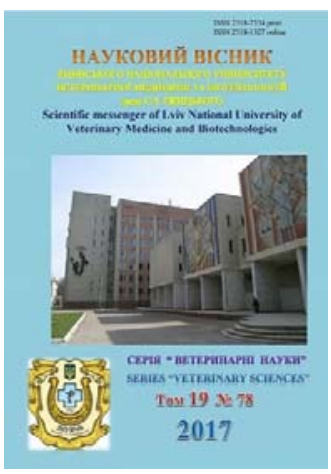

Науковий вісник Львівського національного університету ветеринарної медицини та біотехнологій імені С.З. Гжицького

Scientific Messenger of Lviv National University of Veterinary Medicine and Biotechnologies

doi:10.15421/nvlvet7835

ISSN 2518-7554 print

ISSN 2518-1327 online

$\underline{\text { http://nvlvet.com.ua/ }}$

УДК 619:616.98:619:616.08 (477.83)

\title{
Видовий склад циркулюючої мікрофлори та її стійкість до антибактеріальних препаратів в умовах ПАФ «Бережниця» Жидачівського району Львівської області
}

\author{
Я.В. Кісера, Ю.Г. Сторчак, Л.Я. Божик \\ kisera53@ukr.net,juliettus1@gmail.com \\ Львівський національний університет ветеринарної медиџини та біотехнологій імені С.З. Гжиџького, \\ вул. Пекарська, 50, Львів, 79010, Україна
}

\begin{abstract}
Головним питанням сьогодення є забезпечення безпечної та якісної тваринницької продукції із врахуванням усіх аспектів виробництва продуктів харчування, від ферми до столу. 3 метою збереженості молодняку тварин, підвищення опірності імунної системи організму, запобігання впливу інфекиійних патогенів на макроорганізм та навколишнє середовище проведені дослідження з визначення ииркулюючої в умовах господарства мікрофлори. Бактеріологічні дослідження включали в себе посів досліджуваного матеріалу на живильні середовища, їх ідентифікцію та вивчення чутливості до антибіотиків. Для проведення аналізу чутливості мікроорганізмів до лікарських (антибактеріальних) речовин дискодифузійним методом використовували на поживне середовище АГВ, на яке «газоном» висівали аналізуючі культури та використовували диски з антибактеріальними препаратами. За результатами бактеріологічних досліджень проб молока встановлено, щзо у 70\% досліджуваних проб патогенної мікрофлори не виділено. У 30\% досліджуваних проб встановлено наявність у пробах молока таких патогенних мікроорганізмів, як Staphylococcus aureus та Proteus vulgaris. Бактеріологічні дослідження ексудату з піхви, відібраного у корів після отелу, засвідчили наявність у них Streptococcus epidermidis, Enterobacter cloacae, Escherichia coli, Proteus vulgaris ma плісеневих грибів роду Aspergillus spp. Дослідженнями ексудату з носових ходів та зіву у телят встановлено, що у всіх досліджуваних пробах присутня Escherichia coli. Результатами досліджень калу телят встановлена наявність ряду мікроорганізмів: Escherihia coli, Proteus vulgaris, Escherihia coli haemolitica, Staphylococcus haemoliticus, плісеневих грибів роду Aspergillus у різних відсоткових співвідношеннях. При визначенні чутливості виділених культур до антибактеріальних препаратів встановлено, щь культури Staphylococcus ma Escherihia coli haemolitiса є чутливими до всіх антибіотиків; Proteus vulgaris проявив стійкість до ампіциліну, амоксицикліну.

Ключові слова: біологічна безпека, факторні хвороби, умовно-патогенна мікрофлора, молоко, фекалії, Escherichia coli, Proteus vulgaris, плісеневі гриби роду Aspergillus, антибактеріальні препарати, стійкість.
\end{abstract}

\section{Видовой состав циркулирующей микрофлоры и ее стойкость к антибактериальным препаратам в условиях ЧАФ «Бережница» Жидачевского района Львовской области}

\author{
Я.В. Кисера, Ю.Г. Сторчак, Л.Я. Божик \\ kisera53@ukr.net, juliettus1@gmail.com
}

Львовский национальный университет ветеринарной медицины и биотехнологий имени С.3. Гжицкого, ул. Пекарская, 50, г. Львов, 79010, Украина

Главным вопросом сегодня является обеспечение безопасной и качественной животноводческой продукиии с учетом всех аспектов производства продуктов питания, от фермы до стола. С иелью сохранности молодняка животных, повышения сопротивляемости иммунной системы организма, предотвращения воздействия инфекиионных патогенов на мак-

\section{Citation:}

Kisera, Y.V., Storchak, Y.G., Bozsik, L.Y. (2017). Special composition of circular microflora and its stability to antibacterial preparations in the conditions of PAF «Brezhnitsya» of the Zhedachivsky district of Lviv region. Scientific Messenger LNUVMB, 19(78), 172-176. 
роорганизм и окружаюшую среду проведены исследования по определению циркулируюшей в условиях хозяйства микрофлоры. Бактериологические исследования включали в себя посев исследуемого материала на питательнье средь, их идентификцию и изучение чувствительности к антибиотикам. Для проведения анализа чувствительности микроорганизмов к лекарственным (антибактериальным) препаратам диско-диффузным методом использовали питательную среду АГВ, на которую «газоном» высевали анализирующие культуры и использовали диски с антибактериальными препаратами. По результатам бактериологических исследований проб молока установлено, что у $70 \%$ исследуемых проб патогенную микрофлору не выделено. В 30\% исследуемых проб установлено наличие в пробах молока таких патогенных микроорганизмов, как Staphylococcus aureus и Proteus vulgaris. Бактериологические исследования экссудата из влагалища, отобранного у коров после отела, показали наличие в них Streptococcus epidermidis, Enterobacter cloacae, Escherichia coli, Proteus vulgaris $u$ плесневых грибов рода Aspergillus spр. Исследованиями экссудата из носовых ходов и зева у телят установлено, что во всех исследуемых пробах присутствует Escherichia coli. Результатами исследований кала телят установлено наличие ряда микроорганизмов: Escherihia coli, Proteus vulgaris, Escherihia coli haemolitica, Staphylococcus haemoliticus, nлесневых грибов рода Aspergillus в разных процентных соотношениях. При определении чувствительности выделенных культур к антибактериальным препаратам установлено, что культуры Staphylococcus и Escherihia coli haетоlitica чувствительны ко всем антибиотикам Proteus vulgaris проявил устойчивость к ампициллину, амоксициклин.

Ключевые слова: биологическая безопасность, факторные болезни, условно-патогенная микрофлора, молоко, фекалии, Escherichia coli, Proteus vulgaris, плесневые грибы рода Aspergillus, антибактериальные препараты, устойчивость.

\title{
Special composition of circular microflora and its stability to antibacterial preparations in the conditions of PAF «Brezhnitsya» of the Zhedachivsky district of Lviv region
}

\author{
Y.V. Kisera, Y.G. Storchak, L.Y. Bozsik \\ kisera53@ukr.net, juliettus1@gmail.com \\ Stepan Gzhytskyi National University of Veterinary Medicine and Biotechnologies Lviv, \\ Pekarska Str., 50, Lviv, 79010, Ukraine
}

\begin{abstract}
The main issue today is the provision of safe and high-quality livestock products, taking into account all aspects of food production, from farm to table. In order to preserve the young animals, increase the resistance of the immune system of the organism, prevent the influence of infectious pathogens on macroorganism and the environment, studies have been conducted to determine the microflora circulating in the conditions of the economy. In particular, from the point of view of food safety, E. coli is a dangerous factor affecting their quality, causing various diseases in humans and animals. In the body of a healthy bovine animal, Escherichia coli may be present in an admissible concentration of up to 107 CFUs, Escherichia coli haemolitica is normally absent in the animal body. Bacteriological studies included seeding of the test material on the nutrient medium, their identification and the study of antibiotic susceptibility. For the analysis of the sensitivity of microorganisms to medicinal (antibacterial) substances by disco-diffusion method, they used a nutrient medium of $A G V$, on which the «lawn» was sown analyzing cultures and used discs with antibacterial preparations. According to the results of bacteriological studies of milk samples, it has been determined that $70 \%$ of the examined samples of pathogenic microflora have not been isolated. In 30\% of the tested samples, the presence of pathogenic microorganisms such as Staphylococcus aureus and Proteus vulgaris in milk samples was established. Bacteriological studies of vaginal exudate taken from cows after the calving have shown that they have Streptococcus epidermidis, Enterobacter cloacae, Escherišhia coli, Proteus vulgaris and fungus of the genus Aspergillus spp. Investigations of the exudate from the nasal passages and the calving of the calves have revealed that Escherichia coli is present in all the samples tested. The results of studies of calf sturgeon revealed the presence of a number of microorganisms: Escherihia coli, Proteus vulgaris, Escherihia coli haemolitica, Staphylococcus haemoliticus, molds of the genus Aspergillus in different percentages. When determining the sensitivity of isolated cultures to antibacterial drugs by the disc diffusion method, it has been established that Staphylococcus and Escherihia coli haemolitica cultures are susceptible to all antibiotics; Proteus vulgaris exhibits resistance to ampicillin, amoxicillin.
\end{abstract}

Key words: biological safety, factor diseases, conditionally pathogenic microflora, milk, feces, Escherichia coli, Proteus vulgaris, molds of the genus Aspergillus, antibacterial drugs, resistance.

\section{Вступ}

Недотримання санітарно-гігієнічних правил утримання тварин, застосування інтенсивних технологій та надмірне скупчення тварин - усе це сприяє виникненню асоціативних захворювань, особливо серед молодняку тварин. Доведено, що в інфекційній патології тварин домінуюче значення мають умовно патогенні бактерії, які спричиняють факторні інфекції. На долю цих хвороб припадає 81,4\% випадків (Peleno, 2012).

3 точки зору безпеки харчових продуктів E. coli $€$ небезпечним чинником, що впливає на їх якість (Bean and Griffin, 1990; Mead et al., 1999; Bryan, 2001). Шта- ми E. coli викликають різні захворювання у людини та тварин. Гемолітична E. coli може призвести до геморагічного коліту, гемолітичного уремічного синдрому та тромботичної тромбоцитопенічної хвороби. В організмі здорової великої рогатої худоби Escherichia coli може знаходитися у допустимій концентрації до $10^{7}$ КУО, Escherichia coli haemolitica в організмі тварин у нормі не повинно бути (Dorn, 1993; Boyce et al., 1995).

3 метою збереженості молодняку тварин, підвищення опірності імунної системи організму необхідно проводити дослідження циркулюючої в умовах господарств мікрофлори. Визначення видового складу циркулюючої мікрофлори, іiі вірулентність та стій- 
кість до антибактеріальних препаратів $\epsilon$ важливим фактором біологічного захисту (Holovko, 2009).

Мета $і$ завдання досліджень: визначити в умовах ПАФ «Бережниця» Жидачівського району Львівської області видовий склад циркулюючої бактеріальної мікрофлори та іiі стійкість до антибактеріальних препаратів. Для досягнення даної мети були поставлені наступні завдання: провести бактеріологічні дослідження змивів 3 носа, зіву та калу, відібраних від телят; секрет із молочної залози та ексудат із матки у корів; вивчити морфологічні властивості бактеріальної мікрофлори, процентне співвідношення ії̈ видового складу та визначити чутливість до антибіотиків.

\section{Матеріал та методи досліджень}

Дослідження проводились у ПАФ «Бережниця» Жидачівського району Львівської області, в умовах кафедри епізоотології Львівського національного університету ветеринарної медицини та біотехнологій імені С.3. Гжицького. Для досліджень від корів після отелу відбирали молоко та ексудат 3 піхви, від телят 2-тижневого віку - змиви з носа, зіву та кал. У дослідах було задіяно 20 корів та 20 телят симентальської породи.
Бактеріологічні дослідження проводились за методикою Висоцького А.Є із співавторами, які включали посів досліджуваного матеріалу на живильні середовища, висів отриманих культур на диференціальні середовища 3 метою визначення їх морфологічних властивостей, вивчення їх чутливості до антибіотиків (Vysockij and Baranovskaja, 2002; Guardabassi, 2008; Levkivska et al., 2017). Для вивчення антибіотикочутливості ізоляти висівали на середовище АГВ та використовували диски 3 антибактеріальними препаратами.

\section{Результати та їх обговорення}

За результатами бактеріологічних досліджень молока (табл. 1) встановлено, що у 70\% досліджуваних проб патогенної та умовно-патогенної мікрофлори виділено не було. У $30 \%$ досліджуваних проб було встановлено наявність у пробах молока Staphylococcus aureus у кількості $10^{2}$ та Proteus vulgaris у кількості $10^{4}$.

Бактеріологічні дослідження матеріалу, відібраного 3 піхви від корів після отелу (табл. 2), засвідчили наявність у них Streptococcus epidermidis, Enterobacter cloacae, Escherihia coli, Proteus vulgaris, Staphylococcus haemolyticus та плісеневих грибів роду Aspergillus spp.

Таблиия 1

Видовий склад патогенної мікрофлори молока, $\mathbf{n}=\mathbf{2 0}$

\begin{tabular}{|c|c|c|}
\hline № п/п & Назва мікроорганізму & Концентрація збудника, КУО \\
\hline 1 & Staphylococcus aureus & $10^{2}$ \\
\hline 2 & Proteus vulgaris & $10^{4}$ \\
\hline
\end{tabular}

Таблиия 2

Концентрація мікроорганізмів, виділених 3 піхви від корів після отелу, КУО, $\mathbf{n}=20$

\begin{tabular}{|c|c|c|c|c|c|c|}
\hline $\begin{array}{l}\text { № } \\
\Pi / \Pi \\
\end{array}$ & $\begin{array}{l}\text { Proteus } \\
\text { vulgaris }\end{array}$ & $\begin{array}{l}\text { Streptococcus } \\
\text { epidermidis }\end{array}$ & $\begin{array}{c}\text { Escherichia } \\
\text { coli }\end{array}$ & $\begin{array}{c}\text { Enterobacter } \\
\text { cloacae }\end{array}$ & $\begin{array}{c}\text { Staphylococcus } \\
\text { haemolyticus }\end{array}$ & Aspergillus spp. \\
\hline 1 & - & $10^{2}$ & $10^{3}$ & - & - & + \\
\hline 2 & $10^{3}$ & - & $10^{5}$ & - & - & + \\
\hline 3 & $10^{3}$ & - & - & $10^{3}$ & - & + \\
\hline 4 & - & - & $10^{5}$ & - & $10^{3}$ & - \\
\hline 5 & $10^{4}$ & - & $10^{2}$ & - & - & + \\
\hline 6 & - & $10^{2}$ & $10^{2}$ & - & - & + \\
\hline 7 & $10^{3}$ & - & $10^{5}$ & - & - & + \\
\hline 8 & $10^{2}$ & - & - & $10^{5}$ & - & + \\
\hline 9 & - & - & $10^{3}$ & - & $10^{4}$ & - \\
\hline 10 & $10^{4}$ & - & $10^{5}$ & - & - & + \\
\hline 11 & - & $10^{2}$ & $10^{4}$ & - & - & + \\
\hline 12 & $10^{3}$ & - & $10^{5}$ & - & - & + \\
\hline 13 & $10^{2}$ & - & - & $10^{5}$ & - & + \\
\hline 14 & - & - & $10^{5}$ & - & $10^{3}$ & - \\
\hline 15 & $10^{3}$ & - & $10^{2}$ & - & - & - \\
\hline 16 & - & $10^{2}$ & $10^{5}$ & - & - & + \\
\hline 17 & $10^{3}$ & - & $10^{5}$ & - & - & + \\
\hline 18 & $10^{2}$ & - & - & $10^{4}$ & - & + \\
\hline 19 & - & - & $10^{5}$ & - & $10^{2}$ & + \\
\hline 20 & $10^{4}$ & - & $10^{3}$ & - & - & - \\
\hline
\end{tabular}

3 20-и досліджуваних проб у 16-и пробах виділено Escherichia coli, у 15-и пробах - Aspergillus spp, . у 12и пробах - Proteus vulgaris, у 4-х пробах - Staphylococcus haemoliticus, у 4-х пробах - Streptococcus epidermidis, у 4-х пробах - Enterobacter cloacae.
Дослідженнями ексудату з носових ходів та зіву у телят (табл. 3) встановлено, що у всіх 20-и досліджуваних пробах присутня E. coli. У 4 пробах виявлено Proteus vulgaris, Proteus morganii, Citrobacter spp., Enterobacter cloacae. 
Концентрація мікроорганізмів, виділених 3 носа і зіву телят, КУО, $\mathbf{n}=20$

\begin{tabular}{|c|c|c|c|c|c|}
\hline$№$ ก/п & Proteus vulgaris & Proteus morganii & Escherichia coli & Enterobacter cloacae & Citrobacter spp. \\
\hline 1 & - & - & $10^{3}$ & - & - \\
\hline 2 & - & - & $10^{2}$ & - & - \\
\hline 3 & $10^{2}$ & - & $10^{4}$ & - & $10^{2}$ \\
\hline 4 & - & - & $10^{3}$ & - & - \\
\hline 5 & - & $10^{3}$ & $10^{2}$ & - & - \\
\hline 6 & - & - & $10^{3}$ & - & - \\
\hline 7 & - & - & $10^{2}$ & $10^{2}$ & - \\
\hline 8 & $10^{2}$ & - & $10^{3}$ & - & - \\
\hline 9 & - & $10^{2}$ & $10^{3}$ & - & - \\
\hline 10 & - & - & $10^{2}$ & $10^{2}$ & - \\
\hline 11 & - & - & $10^{4}$ & - & - \\
\hline 12 & - & $10^{3}$ & $10^{3}$ & - & $10^{2}$ \\
\hline 13 & - & - & $10^{2}$ & - & - \\
\hline 14 & $10^{3}$ & - & $10^{3}$ & $10^{4}$ & - \\
\hline 15 & - & - & $10^{2}$ & - & - \\
\hline 16 & - & - & $10^{2}$ & - & - \\
\hline 17 & - & $10^{4}$ & $10^{4}$ & - & - \\
\hline 18 & $10^{3}$ & - & $10^{3}$ & - & $10^{3}$ \\
\hline 19 & - & - & $10^{2}$ & & - \\
\hline 20 & - & - & $10^{2}$ & & - \\
\hline
\end{tabular}

Як видно з таблиці 4 при досліджені 20-и проб калу телят виявлено Escherichia coli у всіх пробах, Proteus vulgaris у 15-и пробах, Enterobacter faecalis у 6-и пробах, Escherichia coli haemolitica у 3-х пробах,
Staphylococcus haemoliticus у 4-х пробах, Staphylococcus aureus у 4-х пробах, плісеневі гриби роду Aspergillus у 6-и пробах.

Концентрація мікроорганізмів, виділених з калу від телят, КУО, $\mathbf{n}=20$

\begin{tabular}{|c|c|c|c|c|c|c|c|}
\hline № $\Pi / \Pi$ & Pr. vulgaris & E. coli & E. coli haem. & $\begin{array}{c}\text { Enterobacter } \\
\text { faecalis }\end{array}$ & S. haemolyticus & S. aureus & Asp. spp. \\
\hline 1 & $10^{3}$ & $10^{3}$ & - & - & - & - & + \\
\hline 2 & $10^{2}$ & $10^{5}$ & $10^{4}$ & - & - & $10^{4}$ & - \\
\hline 3 & $10^{4}$ & $10^{4}$ & - & - & $10^{2}$ & - & - \\
\hline 4 & - & $10^{5}$ & - & - & - & - & - \\
\hline 5 & $10^{4}$ & $10^{4}$ & - & $10^{4}$ & - & - & - \\
\hline 6 & $10^{5}$ & $10^{4}$ & - & $10^{3}$ & - & - & + \\
\hline 7 & $10^{2}$ & $10^{4}$ & $10^{4}$ & - & - & $10^{5}$ & + \\
\hline 8 & $10^{3}$ & $10^{4}$ & - & - & - & - & - \\
\hline 9 & $10^{3}$ & $10^{5}$ & - & $10^{5}$ & - & - & - \\
\hline 10 & $10^{4}$ & $10^{3}$ & - & - & - & - & - \\
\hline 11 & $10^{4}$ & $10^{4}$ & - & - & - & - & - \\
\hline 12 & $10^{2}$ & $10^{5}$ & - & $10^{5}$ & - & - & - \\
\hline 13 & - & $10^{3}$ & - & - & - & - & - \\
\hline 14 & - & $10^{5}$ & - & - & - & - & - \\
\hline 15 & $10^{4}$ & $10^{4}$ & - & $10^{4}$ & - & - & + \\
\hline 16 & $10^{4}$ & $10^{5}$ & - & - & - & & + \\
\hline 17 & - & $10^{3}$ & $10^{3}$ & - & - & - & + \\
\hline 18 & $10^{2}$ & $10^{2}$ & - & - & - & - & - \\
\hline 19 & - & $10^{5}$ & - & $10^{5}$ & - & - & - \\
\hline 20 & $10^{5}$ & $10^{4}$ & - & - & - & - & - \\
\hline
\end{tabular}

При визначенні чутливості виділених культур до антибактеріальних препаратів (табл. 5) встановлено, що стафілокок чутливий до всіх антибіотиків; протей проявив стійкість до ампіциліну, амоксицикліну та чутливість до цефотоксиму, цефтріаксону, цефтазидиму, гентаміцину, іміпінему, цефенілу, цефоперазону, імікацину, цефнірому; гемолітична ешерихія чутлива до всіх антибактеріальних препаратів.

Отже, результати досліджень засвідчили, що в умовах господарства серед великої рогатої худоби циркулює така мікрофлора: Staphylococcus aureus, Staphylococcus haemoliticus, Streptococcus epidermidis, Proteus vulgaris, Proteus morganii, Enterobacter cloacae, Enterobacter faecalis, Escherichia coli, Escherichia coli haemolitica, Citrobacter spp., плісеневі гриби роду Aspergillus. Встановлено, що досліджувані культури чутливі до всіх антибіотиків, що свідчить про відсутність резистентності до антибіотиків через неконтрольоване їх використання. 
Чутливість виділених патогенних культур до антибактеріальних препаратів

\begin{tabular}{|c|c|c|c|}
\hline Назва антибактеріального препарату & Staphylococcus aureus & Proteus vulgaris & Escherichia coli haemolytica \\
\hline Оксацилін & $\mathrm{Y}$ & $\mathrm{\Psi}$ & $\mathrm{\Psi}$ \\
\hline Еритроміцин & $\mathrm{Y}$ & $\mathrm{Y}$ & $\mathrm{Y}$ \\
\hline Кліндаміцин & Ч & Ч & Ч \\
\hline Ципрофлоксацин & $\mathrm{Y}$ & $\mathrm{Y}$ & $\mathrm{\Psi}$ \\
\hline Гентаміцин & $\mathrm{Y}$ & Ч & Ч \\
\hline Ванкоміцин & Ч & Ч & Ч \\
\hline Тетрациклін & Ч & $\mathrm{\Psi}$ & $\mathrm{Y}$ \\
\hline Ріфампіцин & $\mathrm{Y}$ & Ч & $\mathrm{Y}$ \\
\hline Лінезолід & Ч & Ч & Ч \\
\hline Цефпіром & $\mathrm{\Psi}$ & $\mathrm{\Psi}$ & $\mathrm{Y}$ \\
\hline Іміпінем & $\mathrm{Y}$ & $\mathrm{Y}$ & $\mathrm{\Psi}$ \\
\hline Ампіцилін & $\mathrm{Y}$ & $\mathrm{P}$ & $\mathrm{P}$ \\
\hline Амоксициклін & $\mathrm{Y}$ & $\mathrm{P}$ & Ч \\
\hline Цефотоксим & $\mathrm{Y}$ & Ч & $\mathrm{\Psi}$ \\
\hline Цефтріаксон & $\mathrm{Y}$ & $\mathrm{Y}$ & $\mathrm{Y}$ \\
\hline Цефтазидим & $\mathrm{Y}$ & $\mathrm{Y}$ & $\mathrm{Y}$ \\
\hline Цефенім & $\mathrm{\Psi}$ & $\mathrm{\Psi}$ & $\mathrm{\Psi}$ \\
\hline Цефоперазон & $\mathrm{\Psi}$ & $\mathrm{\Psi}$ & $\mathrm{Y}$ \\
\hline Амікацин & $\mathrm{Y}$ & $\mathrm{Y}$ & $\mathrm{Y}$ \\
\hline
\end{tabular}

\section{Висновки}

1. Бактеріологічним дослідженнями молока та ексудату з піхви, відібраних від корів після отелу, встановлена наявність Streptococcus epidermidis, Enterobacter cloacae, Escherichia coli, Proteus vulgaris ma плісеневих грибів роду Aspergillus spp.

2. Зі змивів з носа, зіву та калу, відібраних від телят, виділено Escherichia coli, Proteus та плісеневі гриби Aspergillus.

3. Досліджувані культури мікроорганізмів є чутливими до антибактеріальних препаратів.

Перспективи подальших досліджень полягають у подальшому ретельному моніторингу циркулюючої мікрофлори 3 метою розробки рекомендацій щодо профілактики захворювань великої рогатої худоби в умовах ПАФ «Бережниця» Жидачівського району Львівської області.

\section{Бібліографічні посилання}

Peleno, R.A. (2012). Epizootolohichnyi monitorynh khvorob svynei V Ukraini. Veterynarna biotekhnolohiia. 21, 330-335 (in Ukrainian).

Bean, N.H., Griffin, P.M.G. (1990). Foodborne disease outbreaks in the US 1973-1987: Pathogens, vehicles, and trends. J. Food Prot. 53, 804-817.

Mead, P.S., Slutsker, L., Dietz, V., McCraig, L.F., Bresee, J.S., Shapiro, C., Griffin, P.M., Tauxe, R.V.
(1999). Food-related illness and death in the United States. Emerg. Infect. Dis. 5, 607-625.

Bryan, F.L. (2001). Reflections on a career in public health: Evolving foodborne pathogens, environmental health, and food safety programs. J. Environ. Health. 65, 14-24.

Dorn, C.R. (1993). Review of food borne outbreak of Escherichia coli O157:H7 infection in the western United States. J. Am. Vet. Med. Assoc. 203:15831587.

Boyce, T.G., Swerdlow, D.L., Griffin, P.M. (1995). Escherichia coli O157:H7 and the hemolyticuremic syndrome. N. Engl. J. Med. 333, 364-368.

Holovko, A.M. (2009). Biolohichna ta henetychna bezpeka Ukrainy Mizhvid. nauk. temat. zbirnyk. «Veterynarna medytsyna». Kharkiv. 92, 10-13 (in Ukrainian).

Vysockij, A.Je., Baranovskaja, Z.N. (2002). Spravochnik po bakteriologicheskim metodam izyskanij v veterinarii. Izdatel'stvo Ministerstva sel'skogo hozjajstva Respubliki Belarus' (in Russian).

Levkivska, N.D., Kurtiak, B.M., Levkivskyi, D.M., Padovskyi, A.I., Gutyj, B.V., Semaniuk, V.I. (2017). Laboratorna diahnostyka infektsiinykh khvorob tvaryn bakterialnoi etiolohii. Lviv: SPOLOM (in Ukrainian).

Guardabassi, L. (2008). Guide to Antimicrobial Use in Animals. Blackwell Publishing. 